\title{
Analysis of quality of life in women treated for incontinence dependent on sociodemographic factors
}

Analiza jakości życia kobiet leczonych z powodu nietrzymania moczu zależnie od czynników socjodemograficznych

\section{Katarzyna Kanadys ${ }^{1}$, Katarzyna Szczekala², Grażyna Stadnicka ${ }^{3}$, Ewelina Woźnica ${ }^{4}$, Henryk Wiktor ${ }^{1}$}

'Department of Obstetrics, Gynaecology and Obstertic and Gynaecological Nursing, Faculty of Health Sciences, Medical University of Lublin/ Zakład Położnictwa, Ginekologii i Pielęgniarstwa Położniczo-Ginekologicznego, Wydział Nauk o Zdrowiu, Uniwersytet Medyczny w Lublinie 2Department of Foreign Languages, I Faculty of Medicine with Dentistry Division, Medical University of Lublin/ Studium Praktycznej Nauki Języków Obcych, Uniwersytet Medyczny w Lublinie ${ }^{3}$ Chair and Department of Development of Obstetrics, Faculty of Health Sciences, Medical University of Lublin/ Katedra i Zakład Rozwoju Położnictwa, Wydział Nauk o Zdrowiu, Uniwersytet Medyczny w Lublinie ${ }^{4} \mathrm{~A}$ graduate of the Faculty of Health Sciences, Medical University of Lublin/ Absolwent Wydziału Nauk o Zdrowiu, Uniwersytetu Medycznego w Lublinie

ORCID:

Katarzyna Kanadys: 0000-0001-8447-3937 Katarzyna Szczekala: 0000-0002-2055-0347

Grażyna Stadnicka: 0000-0002-5850-3247 Henryk Wiktor: 0000-0002-4026-1884

CORRESPONDING AUTHOR/AUTOR DO KORESPONDENCJI:

Katarzyna Kanadys

Zakład Położnictwa, Ginekologii i Pielęgniarstwa Położniczo-Ginekologicznego, Wydział Nauk o Zdrowiu, Uniwersytet Medyczny w Lublinie ul. Chodźki 7, 20-093 Lublin e-mail: katarzyna.kanadys@umlub.pl

STRESZCZENIE

Stowa kluczowe:
ANALIZA JAKOŚCI ŻYCIA KOBIET LECZONYCH Z POWODU NIETRZYMANIA MOCZU ZALEŻNIE OD CZYNNIKÓW SOCJODEMOGRAFICZNYCH

Wstęp. Nietrzymanie moczu charakteryzuje się mimowolnym wyciekiem moczu. Jest problemem, który dotyczy coraz większej liczby kobiet. Najczęściej występuje w okresie okołomenopauzalnym, jednak może pojawić się w każdym wieku. Objawy związane z nietrzymanie moczu powodują u chorych duży dyskomfort, który może warunkować jakość codziennego życia.

Cel pracy. Ocena poziomu jakości życia kobiet z nietrzymaniem moczu zależnie od zmiennych socjodemograficznych.

Materiał i metoda. Badaniami objęto 102 pacjentki oddziału ginekologii SPSK nr 1 i SPSK nr 4 w Lublinie. Kryterium doboru do grupy badanej były: hospitalizowane pacjentki ze stwierdzonym nietrzymaniem moczu w trakcie procesu leczenia. Projekt badania uzyskał pozytywną opinię Komisji Bioetycznej Uniwersytetu Medycznego w Lublinie (Nr KE-0254/25/2016). Badania przeprowadzono metodą sondażu diagnostycznego z wykorzystaniem kwestionariusza ankiety własnego autorstwa oraz kwestionariusza dotyczącego zdrowia (King's Health Questionnaire). Wyniki analizowanych danych zostały poddane analizie statystycznej przyjmując $p<0,05$ za istotne statystycznie.

Wyniki. Wiek warunkował jakość życia badanych kobiet w zakresie wpływu objawów związanych z układem moczowym na ogólny stan zdrowia, relacje partnerskie oraz sen. Wykształcenie nie warunkowało wpływu objawów związanych z układem moczowym na poszczególne domeny jakości życia badanej przy użyciu kwestionariusza King's Health. Stan cywilny był zmienną warunkującą jakość życia respondentek. Sytuacja finansowa warunkowała wpływ objawów związanych z układem moczowym na ogólny stan zdrowia, kondycję fizyczną oraz sen.

Wnioski. Jakość życia kobiet z nietrzymaniem moczu była warunkowana przez ich wiek, stan cywilny oraz sytuację finansową. Kobiety powyżej 65 roku życia, będące wdowami lub rozwódkami z przeciętną sytuacją finansową charakteryzowały się gorszą jakością życia aniżeli kobiety z młodszych grup wiekowych, będące mężatkami oraz z dobrą sytuacją finansową.

nietrzymania moczu, jakość życia, kobiety 


\section{FACTORS}

Introduction. Urinary incontinence (UI) constitutes involuntary leakage of urine and concerns an increasing number of women. It usually occurs in perimenopausal period; however, it may occur any time. Symptoms typical of incontinence cause massive discomfort that can affect the quality of life (QoL).

Aim. The assessment of the QoL in women suffering from UI dependent on sociodemographic variables.

Material and methods. The research encompassed 102 patients of the gynaecological wards of the Independent Clinical Hospital No 1 in Lublin and the Independent Public Clinical Hospital No 4 in Lublin. The inclusion criterion was as follows female patients diagnosed with urinary incontinence and treated in hospital. The study was voluntary and anonymous. The research project was approved by the Bioethics Committee of the Medical University of Lublin (No KE-0254/25/2016). The method of diagnostic survey was applied by means of the authors' own questionnaire and the King's Health Questionnaire (KHQ). The statistical analysis of the data results was carried out and $p<0.05$ was assumed as statistically significant.

Results. Age conditioned the $\mathrm{Q} O \mathrm{~L}$ in the females researched regarding the influence of the urinary tract symptoms on their general health, partner relations and sleep. The females over 65 years of age showed worse $\mathrm{Q} 0 \mathrm{~L}$ in comparison with the younger ones. Education did not affect the impact of urinary symptoms on the domains of the $\mathrm{QOL}$ using the KHQ. The marital status was a variable that influenced the respondents' $\mathrm{Q} \mathrm{oL}$. The married women had better $\mathrm{Q}_{\mathrm{o}} \mathrm{L}$ than the widowed or divorced ones. The financial situation conditioned the impact of the urinary symptoms on their general health, physical condition and sleep. The females with the average financial situation had worse QoL than those with good financial situation.

Conclusions. The QoL of women with UI depended on their age, marital status and financial situation. The females over 65 years of age who were widowed or divorced with the average financial situation were characterised by worse QoL than the younger and married women with good financial situation.

Key words: urinary incontinence, quality of life, women

\section{INTRODUCTION}

Urinary incontinence (UI) constitutes involuntary leakage of urine $[1,2]$. This considerable health problem concerns approximately $10 \%$ of the population; it is the most common in females, though it also occurs in males. The frequency in females at the middle and older age is estimated in the range of $30-60 \%[2,3]$. Women at the perimenopausal period are affected most but the problem may occur any time [2].

Issues connected with UI influence each sphere of life in women. They cause mental, social and hygienic discomfort. The quality of life (QoL), both private and professional one, is considerably worsened. Those women limit social meetings very frequently, they even resign from work. The withdrawal results from shame and embarrassment and in extreme cases may lead to complete social isolation or depression [4-7]. The problem of incontinence also affects sexual life of partners disturbing it effectively $[8,9]$.

UI is frequently hidden as individuals do not report it to their physicians treating the complaint as too embarrassing. It happens that it is also seen as a natural complaint typical of aging. Thus, even their nearest relatives are not informed about the problem. Frequently, the individuals are not aware of the possibility of treating it, so the only possible way for them is accepting it and getting accustomed to their life with this disease. Although the problem of UI affects increasingly more females, it still remains a taboo $[4,10,11]$.

\section{MATERIALS AND METHODS}

The research encompassed 102 patients of Gynaecology at the Independent Public Clinical Hospital No 1 in Lublin and the Independent Public Clinical Hospital No 4 in Lublin. The inclusion criterion to the research group was the diagnosis of UI during the process of treatment. The study was voluntary and anonymous. The project of the study was approved by the Bioethics Committee of the Medical University of Lublin (No KE-0254/25/2016).

The study was carried out by means of the diagnostic survey method using the authors' own questionnaire compiled for this particular purpose and the Polish version of the King's Health Questionnaire (KHQ).

The KHQ concerns health and the Polish version was obtained with the consent of the MAPI Research Trust. The questionnaire appears to be divided into three parts. The first one assesses general health and symptoms associated with the urinary system affecting mental state. The second part includes questions enabling women to evaluate the influence of urinary symptoms on five spheres of life, namely professional life, rest, social life, daily activities and sexual life. The third part serves to assess the degree of difficulty resulting from dealing with the problem of soaking underwear regarding the necessity to use pads and frequently change clothes (underwear). The respondents assessed the influence of UI symptoms on particular fields of life using the $1-4$ scale [12].

The results obtained were statistically analysed. Nonparametric tests were applied. Two groups were compared by means of the Mann-Whitney U test. To compare more than two groups, the Kruskal-Wallis $\mathrm{H}$ test was utilised. The statistical analysis was performed using the IBM SPSS Statistics software assuming the statistical significance of $\mathrm{p}<0.05$. 


\section{RESULTS}

The analysis of the research results of the QoL using the KHQ dependent on age of females suffering from UI was depicted in Table 1.

Tab. 1. Correlation between particular dimensions of QoL (King's Health) and age of the females researched

\begin{tabular}{|c|c|c|c|c|c|c|c|c|}
\hline \multirow{3}{*}{$\begin{array}{c}\text { The } \\
\text { influence } \\
\text { of urinary } \\
\text { symptoms } \\
\text { on }\end{array}$} & \multicolumn{6}{|c|}{ Age } & \multirow{2}{*}{\multicolumn{2}{|c|}{$\begin{array}{c}\text { Kruskal-Wallis } \\
\text { test }\end{array}$}} \\
\hline & \multicolumn{2}{|c|}{$\begin{array}{l}\text { Up to } 50 \\
\text { years old }\end{array}$} & \multicolumn{2}{|c|}{$\begin{array}{c}51-64 \text { years } \\
\text { old }\end{array}$} & \multicolumn{2}{|c|}{$\begin{array}{c}\text { Over } 65 \\
\text { years old }\end{array}$} & & \\
\hline & M & SD & M & SD & M & SD & Result & $\mathbf{p}$ \\
\hline $\begin{array}{l}\text { General } \\
\text { health }\end{array}$ & 33.09 & 14.72 & 37.86 & 18.56 & 46.21 & 16.68 & 12.939 & 0.002 \\
\hline Everyday life & 70.59 & 25.64 & 72.38 & 23.55 & 76.77 & 25.66 & 1.413 & 0.493 \\
\hline $\begin{array}{l}\text { Functions } \\
\text { or duties } \\
\text { fulfilled }\end{array}$ & 61.76 & 26.44 & 61.43 & 28.80 & 68.18 & 27.44 & 0.450 & 0.798 \\
\hline $\begin{array}{l}\text { Physical } \\
\text { condition }\end{array}$ & 57.35 & 25.02 & 59.52 & 26.90 & 60.10 & 26.33 & 1.414 & 0.493 \\
\hline $\begin{array}{l}\text { Restrictions } \\
\text { of social } \\
\text { roles }\end{array}$ & 30.39 & 25.85 & 40.79 & 27.71 & 42.09 & 27.46 & 3.384 & 0.184 \\
\hline $\begin{array}{l}\text { Partner } \\
\text { relationships }\end{array}$ & 39.71 & 28.43 & 55.91 & 28.07 & 42.86 & 21.21 & 6.245 & 0.044 \\
\hline Mental state & 43.14 & 29.05 & 50.79 & 25.61 & 55.22 & 23.49 & 3.528 & 0.171 \\
\hline Sleep & 34.80 & 24.40 & 45.24 & 20.44 & 51.01 & 22.80 & 8.619 & 0.013 \\
\hline $\begin{array}{l}\text { Prevention } \\
\text { measures }\end{array}$ & 64.46 & 24.90 & 70.24 & $\mid 16.21$ & 62.12 & 20.84 & 2.281 & 0.320 \\
\hline
\end{tabular}

In the study conducted, mean values of the KHQ results obtained in females over 65 years of age were significantly higher, what shows worse QoL in the following domains: general health ( $\mathrm{p}=0.002)$, influence on partners' relations ( $\mathrm{p}=0.044)$ and influence on sleep (0.013) comparing to younger groups. No statistically significant differences were found in the remaining domains ( $p>0.05)$.

The research revealed that age conditioned the influence of urinary symptoms on general health, partners' relations and sleep, what means that females over 65 years old had worse QoL than younger ones.

Furthermore, the analysis of the KHQ research results of QoL was conducted dependent on the respondents' education. However, no statistically significant dependences were found between education and the influence of urinary tract symptoms in the women researched.

The research showed that education did not condition the influence of urinary tract symptoms on particular domains of QoL using the KHQ.

The analysis of the research data of the QoL using the KHQ dependent on marital status of the females researched revealed that mean values obtained in women living alone were significantly higher, namely those women showed worse QoL in the domains such as general health $(\mathrm{p}=0.04)$, influence on mental state $(\mathrm{p}=0.049)$, influence on sleep (0.000) than in the group of women living with their partners/families. In other domains, no statistically significant differences were found ( $p>0.05)$.
The study indicated that marital status conditioned the influence of urinary symptoms on general health, mental state and sleep, which means that females living alone had worse QoL in the abovementioned domains than married ones.

The analysis of the research data regarding the QoL using the KHQ dependent on financial situation of the females researched was demonstrated in Table 2.

Tab. 2. Correlation between particular dimensions of QoL (King's Health) and financial situation of the females researched

\begin{tabular}{|l|c|c|c|c|c|c|}
\hline \multirow{2}{*}{$\begin{array}{l}\text { The influence of } \\
\text { urinary symptoms on }\end{array}$} & \multicolumn{3}{|c|}{ Financial situation } & \multicolumn{2}{c|}{ Kruskal-Wallis test } \\
\cline { 2 - 6 } & Good & \multicolumn{2}{c|}{ Average } & \multicolumn{2}{c|}{} \\
\cline { 2 - 6 } & $\mathbf{M}$ & SD & M & SD & Result & p \\
\hline General health & 34.37 & 13.27 & 43.05 & 19.67 & $\mathbf{9 8 9 . 5 0 0}$ & $\mathbf{0 . 0 2 1}$ \\
\hline Everyday life & 69.44 & 25.57 & 76.54 & 23.90 & 1103.000 & 0.161 \\
\hline $\begin{array}{l}\text { Functions or duties } \\
\text { fulfilled }\end{array}$ & 61.11 & 27.78 & 66.04 & 27.27 & 1167.000 & 0.368 \\
\hline Physical condition & 58.68 & 27.28 & 59.25 & 24.79 & 1274.000 & 0.879 \\
\hline $\begin{array}{l}\text { Restrictions of social } \\
\text { roles }\end{array}$ & 33.44 & 28.91 & 41.56 & 25.37 & 1050.000 & 0.093 \\
\hline Partner relationships & 43.58 & 26.10 & 51.01 & 30.88 & 568.500 & 0.384 \\
\hline Mental state & 42.59 & 27.44 & 55.96 & 23.93 & $\mathbf{8 9 5 . 5 0 0}$ & $\mathbf{0 . 0 0 7}$ \\
\hline Sleep & 38.19 & 22.53 & 48.45 & 23.18 & $\mathbf{9 5 7 . 5 0 0}$ & $\mathbf{0 . 0 1 8}$ \\
\hline Prevention measures & 62.32 & 21.60 & 68.67 & 20.14 & 1066.000 & 0.120 \\
\hline
\end{tabular}

On the basis of the analysis performed, mean values of the KHQ research data in females with average financial situation were slightly higher, what indicates worse QoL in the following domains: general health $(\mathrm{p}=0.021)$, influence on physical condition $(\mathrm{p}=0.007)$ and influence on sleep $(\mathrm{p}=0.018)$, than women having good financial situation. In other domains, no statistically significant differences were found $(p>0.05)$.

The research revealed that financial situation conditioned the impact of urinary tract symptoms on general health, physical condition and sleep. The females declaring average financial situation had worse QoL in the domains than those with good financial situation.

\section{DISCUSSION}

Urinary incontinence (UI) and overactive bladder $(\mathrm{OAB})$ constitute an increasingly more common cause of low quality of life (QoL). Lack of control over the disorder leads to a decrease in self-confidence and self-esteem as well as attractiveness in women's evaluation to a substantial extent. All consequences resulting from UI lead to a considerable deterioration in comfort of life and withdrawal from professional, social and family life [4, 6, 13-16].

In the work presented, an attempt of assessment of QoL in females suffering from UI was made depending on sociodemographic factors determining the research group. The factors included age, education, financial situation, and marital status.

The research showed that age conditioned the QoL of women suffering from UI. Significant dependence was found between age and impact of urinary tract symptoms on general health, partner relations and sleep, which 
means that females over 65 years of age had worse QoL in the domains than younger ones. Similarly, the study by Stadnicka et al. [6] indicated that age conditioned a direct influence of symptoms on general health, being active at home or at work, relations with partners, friends and family, sleep disorders, a decreased self-esteem and self-evaluation. The authors cited [6] stated that females over 60 years of age had worse QoL in the domains analysed than younger females. Moreover, the research by Wójtowicz et al. [17] found that UI occurs more frequently in women in perimenopausal or post-menopausal periods. While Barnaś et al. [18] proved that frequency of miction per twenty-four hours increased with age in women with UI, which could deteriorate their QoL. Furthermore, Stothers et al. [19] revealed that age was the most significant factor affecting problems with urination.

Our own research showed that education did not influence the QoL of the women surveyed. Similar findings were obtained by Dutkiewicz et al. [7] who indicated lack of relationship between education and the issue of UI in the women researched. However, different results were described by Barnaś et al. [18] because in the group of women researched education conditioned significantly their QoL. The authors cited [18] proved that the women with higher education had better QoL which was manifested by taking active attitude towards the problem of UI. They did their best to get rid of the symptoms of the disease in contrast to the respondents with secondary and primary education who were passive towards the problem, thus automatically lowering their QoL during daily performance. Szkup-Jabłońska et al. [20] indicated that better QoL in the aspect of mental state was found in the women with higher education than the ones with secondary education.

Another variable analysed in the context of QoL was financial situation. On the basis of our own research, financial situation conditioned the relationship with urinary symptoms and general health, physical condition and sleep. Females declaring average financial situation indicated lower QoL than those with good financial situation. The study by Kamińska et al. [9] regarding social aspect of UI in women showed that a considerable percentage of women stated that the disease affecting their health significantly deteriorates their financial situation. This is mainly connected with such expenses as drugs, absorbent products or appointments with specialists. Such a situation significantly conditioned the QoL that is lower in the females with bad financial situation than in the respondents who assessed their financial situation as good or very good.

To recapitulate the results of our own research, particular psycho-prophylactic care should be planned to embrace women over 65 years of age being widowed or divorced with average financial situation. Such activities would assure improvement of their QoL.

\section{CONCLUSIONS}

1. The QoL of the women with UI is conditioned by their age, marital status and financial situation.

2. The females over 65 years of age who are widowed or divorced and have average financial situation are characterised by lower results in the range of QoL than those who are younger, married and have good financial situation.

\section{Analiza jakości życia kobiet leczonych z powodu nietrzymania moczu zależnie od czynników socjodemograficznych}

\section{WPROWADZENIE}

Nietrzymanie moczu (NTM) to niezależny od naszej woli wyciek moczu $[1,2]$. Jest istotnym problemem zdrowotnym, który dotyczy ok. 10\% ludności. Najczęściej występuje u kobiet, jednak pojawia się również u mężczyzn. Szacunkowa częstość występowania NTM u kobiet w średnim i starszym wieku mieści się w zakresie od 30\% do 60\% [2,3]. Szczególnie narażone są kobiety w okresie okołomenopauzalnym, jednak problem ten może dotknąć kobiety w każdym wieku [2].

Problemy związane z nietrzymaniem moczu wpływają niekorzystanie na każdą sferę życia kobiety. Powodują dyskomfort zarówno psychiczny, społeczny jak i higieniczny. Znacznemu pogorszeniu ulega jakość życia osobistego i zawodowego. Kobiety te bardzo często ograniczają spotkania towarzyskie, niekiedy rezygnują ze swojej pracy. Wycofanie jest spowodowane wstydem i skrępowaniem, może prowadzić w skrajnych przypadkach do całkowitej izolacji społecznej lub depresji $[4,5$, 6 , 7]. Problem nietrzymania moczu wpływa również na życie seksualne partnerów, skutecznie je zaburzając $[8,9]$.
Nietrzymanie moczu bardzo często jest problemem ukrywanym. Osoby $\mathrm{z}$ inkontynencją często nie zgłaszają się do lekarza, uważają występujące u nich dolegliwości za krępujące i wstydliwe. Zdarza się też, że dolegliwości te uznają za naturalne, pojawiające się wraz z wiekiem. Nie mówią o nich nawet swoim najbliższym. Często nie wiedzą nawet o możliwości leczenia i jedyną rzeczą jaka im pozostaje jest zaakceptowanie i przyzwyczajenie się do życia z chorobą. Problem nietrzymania moczu, mimo iż dotyka coraz większej ilości kobiet wciąż jest tematem na który się nie rozmawia $[4,10,11]$.

\section{MATERIAŁ I METODY}

Badaniami objęto 102 pacjentki oddziału ginekologii Samodzielnego Publicznego Szpitala Klinicznego nr 1 w Lublinie oraz Samodzielnego Publicznego Szpitala Klinicznego nr $4 \mathrm{w}$ Lublinie. Kryterium doboru do grupy badanej było stwierdzone nietrzymanie moczu w trakcie 
procesu leczenia. Badania były dobrowolne i anonimowe. Projekt badania uzyskał pozytywną opinię Komisji Bioetycznej Uniwersytetu Medycznego w Lublinie (Nr KE-0254/25/2016).

Badania przeprowadzono metodą sondażu diagnostycznego z wykorzystaniem kwestionariusza ankiety własnego autorstwa do zgromadzenia danych socjodemodraficznych oraz kwestionariusza dotyczącego zdrowia (King's Health Questionnarie-Poland/ Polish Version).

Kwestionariusz dotyczący zdrowia (King's Health Questionnarie-Poland/Polish Version). Polską wersję KHQ uzyskano za zgodą MAPI Research Trust. Kwestionariusz można podzielić na 3 części. Pierwsza część służy do oceny ogólnego stanu zdrowia oraz objawów związanych z układem moczowym na ich stan psychiczny. Druga część zawiera pytania umożliwiające kobietom ocenę wpływu objawów ze strony układu moczowego na pięć innych dziedzin życia, tj. pracę zawodową, wypoczynek, kontakty towarzyskie, codzienne czynności, współżycie płciowe. Trzecia część ocenia stopień trudności wynikający z zabezpieczaniem się przez moczeniem bielizny. Utrudnienia te były związane między innymi z koniecznością noszenia wkładek czy częstą zmianą ubrania (bielizny). Posługując się skalą od 1 do 4 , respondentki oceniały wpływ objawów nietrzymania moczu na poszczególne dziedziny życia [12].

Uzyskane wyniki badań poddano analizie statystycznej. W analizie wyników badań wykorzystano testy nieparametryczne. Dwie grupy porównano testem U Manna-Whitneya. Do porównania więcej niż dwóch grup wykorzystano test H Kruskala-Wallisa. Obliczeń statystycznych dokonano przy użyciu programu IBM SPSS Statistics. Przyjęto poziom istotności $\mathrm{p}<0,05$.

\section{WYNIKI BADAŃ}

Analizę wyników badania jakości życia przy użyciu King's Health Questionnaire (KHQ) zależnie od wieku kobiet z nietrzymaniem moczu przedstawiono w Tabeli 1.

W przeprowadzonych badaniach uzyskane wartości średnie wyników KHQ u kobiet powyżej 65. roku życia były istotnie wyższe, czyli wskazywały na gorszą jakość życia w domenach: ogólny stan zdrowia $(\mathrm{p}=0,002)$, wpływ na relacje partnerskie $(\mathrm{p}=0,044)$ oraz wpływ na sen $(0,013)$, aniżeli w młodszych grupach wiekowych. Nie stwierdzono różnic istotnych statystycznie w pozostałych domenach ( $p>0,05)$.

Badania wykazały, że wiek warunkował wpływ objawów związanych z układem moczowym na ogólny stan zdrowia, relacje partnerskie oraz sen, co oznacza, że kobiety powyżej 65. roku miały w tych wymiarach miały gorszą jakość życia, aniżeli badane w młodszych grupach wiekowych.

Ponadto przeprowadzono analizę wyników badania jakości życia przy użyciu King's Health Questionnaire (KHQ) zależnie od wykształcenia badanych kobiet. Na podstawie analizy wyników badań własnych nie stwierdzono statystycznie istotnych zależności pomiędzy wykształceniem badanych kobiet a wpływem objawów związanych z układem moczowym.
- Tab. 1. Współzależność pomiędzy poszczególnymi wymiarami jakości życia (King's Health) a wiekiem badanych

\begin{tabular}{|c|c|c|c|c|c|c|c|c|}
\hline \multirow{3}{*}{\begin{tabular}{|c|} 
Wpływ \\
objawów \\
związanych \\
z układem \\
moczowym \\
na: \\
\end{tabular}} & \multicolumn{6}{|c|}{ Wiek } & \multirow{2}{*}{\multicolumn{2}{|c|}{$\begin{array}{c}\text { Test } \\
\text { H-Kruskala } \\
\text { Wallisa }\end{array}$}} \\
\hline & \multicolumn{2}{|c|}{ Do 50 lat } & \multicolumn{2}{|c|}{ 51-64 lat } & \multicolumn{2}{|c|}{$\begin{array}{c}\text { Powyżej } \\
65 \text { lat }\end{array}$} & & \\
\hline & M & SD & $M$ & SD & M & SD & Wynik & $\mathbf{p}$ \\
\hline $\begin{array}{l}\text { Ogólny stan } \\
\text { zdrowia }\end{array}$ & 33,09 & 14,72 & 37,86 & 18,56 & 46,21 & 16,68 & 12,939 & 0,002 \\
\hline $\begin{array}{l}\text { Wpływ } \\
\text { na życie } \\
\text { codzienne }\end{array}$ & 70,59 & 25,64 & 72,38 & 23,55 & 76,77 & 25,66 & 1,413 & 0,493 \\
\hline $\begin{array}{l}\text { Wpływ na } \\
\text { pełnione } \\
\text { funkcje }\end{array}$ & 61,76 & 26,44 & 61,43 & 28,80 & 68,18 & 27,44 & 0,450 & 0,798 \\
\hline $\begin{array}{l}\text { Wpływ na } \\
\text { aktywność } \\
\text { fizyczną }\end{array}$ & 57,35 & 25,02 & 59,52 & 26,90 & 60,10 & 26,33 & 1,414 & 0,493 \\
\hline $\begin{array}{l}\text { Wpływ na } \\
\text { ograniczenia } \\
\text { w pełnieniu } \\
\text { ról społecznych }\end{array}$ & 30,39 & 25,85 & 40,79 & 27,71 & 42,09 & 27,46 & 3,384 & 0,184 \\
\hline $\begin{array}{l}\text { Wpływ } \\
\text { na relacje } \\
\text { partnerskie }\end{array}$ & 39,71 & 28,43 & 55,91 & 28,07 & 42,86 & 21,21 & 6,245 & 0,044 \\
\hline $\begin{array}{l}\text { Wpływ na } \\
\text { kondycję } \\
\text { psychiczną }\end{array}$ & 43,14 & 29,05 & 50,79 & 25,61 & 55,22 & 23,49 & 3,528 & 0,171 \\
\hline Wpływ na sen & 34,80 & 24,40 & 4524 & 20,44 & 51,01 & 22,80 & 8,619 & 0,013 \\
\hline $\begin{array}{l}\text { Środki } \\
\text { zapobiegawcze }\end{array}$ & 64,46 & 24,90 & 70,24 & 16,21 & 62,12 & 20,84 & 2,281 & 0,320 \\
\hline
\end{tabular}

Badania wykazały, że wykształcenie nie warunkowało wpływu objawów związanych z układem moczowym na wszystkie poszczególne domeny jakości życia badanej przy użyciu kwestionariusza King's Health.

Analiza wyników badania jakości życia przy użyciu King's Health Questionnaire (KHQ) zależnie od stanu cywilnego badanych kobiet wykazała, że uzyskane wartości średnie wyników KHQ u kobiet samotnych były istotnie wyższe. Mianowicie, kobiety samotne wskazywały na gorszą jakość życia w domenach: ogólny stan zdrowia ( $\mathrm{p}=0,04)$, wpływ na kondycję psychiczną $(\mathrm{p}=0,049)$ oraz wpływ na sen $(0,000)$ aniżeli w grupie kobiet samotnych. Nie stwierdzono różnic istotnych statystycznie w pozostałych domenach $(\mathrm{p}>0,05)$.

Badania wykazały, że stan cywilny warunkował wpływ objawów związanych z układem moczowym na ogólny stan zdrowia, kondycję psychiczną oraz sen, co oznacza, że kobiety samotne miały w tych wymiarach gorszą jakość życia, aniżeli badane będące mężatkami.

Analizę wyników badania jakości życia przy użyciu King's Health Questionnaire (KHQ) zależnie od sytuacji finansowej badanych kobiet przedstawiono w Tabeli 2.

$\mathrm{Na}$ podstawie przeprowadzonej analizy wyników badań własnych wykazano, że wartości średnie wyników KHQ u kobiet w przeciętnej sytuacji finansowej były nieznacznie wyższe co oznacza, że wskazywały na gorszą jakość życia w domenach: ogólny stan zdrowia ( $\mathrm{p}=0,021)$, wpływ na kondycję fizyczną $(\mathrm{p}=0,007)$ oraz wpływ na sen $(\mathrm{p}=0,018)$, aniżeli kobiety będące w dobrej sytuacji finansowej. Nie stwierdzono różnic istotnych statystycznie $\mathrm{w}$ pozostałych domenach $(\mathrm{p}>0,05)$. 
Katarzyna Kanadys, Katarzyna Szczekala, Grażyna Stadnicka, Ewelina Woźnica, Henryk Wiktor

Tab. 2. Współzależność pomiędzy poszczególnymi domenami jakości życia (King's Health) a sytuacją finansową badanych

\begin{tabular}{|c|c|c|c|c|c|c|}
\hline \multirow{3}{*}{$\begin{array}{c}\text { Wpływ objawów } \\
\text { związanych z } \\
\text { układem moczowym } \\
\text { na: }\end{array}$} & \multicolumn{4}{|c|}{ Sytuacja finansowa } & \multirow{2}{*}{\multicolumn{2}{|c|}{$\begin{array}{c}\text { Test H-Kruskala } \\
\text { Wallisa }\end{array}$}} \\
\hline & \multicolumn{2}{|c|}{ Dobra } & \multicolumn{2}{|c|}{ Przeciętna } & & \\
\hline & M & SD & M & SD & Wynik & p \\
\hline Ogólny stan zdrowia & 34,37 & 13,27 & 43,05 & 19,67 & 989,500 & 0,021 \\
\hline $\begin{array}{l}\text { Wpływ na życie } \\
\text { codzienne }\end{array}$ & 69,44 & 25,57 & 76,54 & 23,90 & 1103,000 & 0,161 \\
\hline $\begin{array}{l}\text { Wpływ na pełnione } \\
\text { funkcje }\end{array}$ & 61,11 & 27,78 & 66,04 & 27,27 & 1167,000 & 0,368 \\
\hline $\begin{array}{l}\text { Wpływ na aktywność } \\
\text { fizyczną }\end{array}$ & 58,68 & 27,28 & 59,25 & 24,79 & 1274,000 & 0,879 \\
\hline $\begin{array}{l}\text { Wpływ na ograniczenia } \\
\text { w pełnieniu ról } \\
\text { społecznych }\end{array}$ & 33,44 & 28,91 & 41,56 & 25,37 & 1050,000 & 0,093 \\
\hline $\begin{array}{l}\text { Wpływ na relacje } \\
\text { partnerskie }\end{array}$ & 43,58 & 26,10 & 51,01 & 30,88 & 568,500 & 0,384 \\
\hline $\begin{array}{l}\text { Wpływ na kondycję } \\
\text { psychiczną }\end{array}$ & 42,59 & 27,44 & 55,96 & 23,93 & 895,500 & 0,007 \\
\hline Wpływ na sen & 38,19 & 22,53 & 48,45 & 23,18 & 957,500 & 0,018 \\
\hline Środki zapobiegawcze & 62,32 & 21,60 & 68,67 & 20,14 & 1066,000 & 0,120 \\
\hline
\end{tabular}

Przeprowadzone badania własne wykazały, że sytuacja finansowa warunkowała wpływ objawów związanych z układem moczowym na ogólny stan zdrowia, kondycję fizyczną oraz sen. Kobiety deklarujące przeciętną sytuacją finansową miały w tych wymiarach gorszą jakość życia, aniżeli oceniające swoją sytuację finansową jako dobrą.

\section{DYSKUSJA}

Nietrzymanie moczu i pęcherz nadreaktywny stanowią coraz częstszą przyczynę niskiej jakości życia [1]. Brak kontroli nad tym zaburzeniem powoduje spadek pewności siebie, poczucia własnej wartości oraz w znacznym stopniu w ocenie kobiety zmniejsza jej atrakcyjność. Wszystkie konsekwencje wynikające z nietrzymania moczu prowadzą do znacznego pogorszenia komfortu życia i wycofania się z życia zawodowego, społecznego i rodzinnego $[4,6,13,14,15,16]$.

W prezentowanej pracy podjęto próbę oceny jakości życia kobiet $\mathrm{z}$ nietrzymaniem moczu zależnie od czynników socjodemograficznych charakteryzujących badane kobiety. Do analizowanych czynników zaliczono wiek, wykształcenie, sytuacja finansowa oraz stan cywilny.

Przeprowadzone badania własne wykazały, że wiek warunkował poziom jakości życia kobiet borykających się z problemem nietrzymania moczu. Stwierdzono istotną zależność pomiędzy wiekiem badanych i wpływem objawów związanych z układem moczowym na ogólny stan zdrowia, relacje partnerskie oraz sen, co oznacza, że kobiety powyżej 65 . roku miały w tych wymiarach miały gorszą jakość życia, w porównaniu do badanych kobiet będących w młodszych grupach wiekowych. Podobnie w badaniach przeprowadzonych przez Stadnicką i wsp. [6], którzy wykazali, że wiek ankietowanych kobiet warunkował bezpośredni wpływ objawów na ogólny stan zdrowia, aktywność w domu czy w pracy, relacje z partnerem oraz przyjaciółmi i rodziną, zaburzenia snu, obniżone poczucie własnej wartości oraz samooceny. Cytowani autorzy [6] stwierdzili, że kobiety w wieku powyżej 60. roku miały gorszą jakość życia w analizowanych wymiarach niż kobiety w młodszych grupach wiekowych. Ponadto $w$ badaniach przeprowadzonych przez Wójtowicz i wsp. [17] zaobserwowano, że problem nietrzymania moczu częściej występuje u kobiet będących w okresie okołomenopauzalnym lub po menopauzie niż u kobiet młodszych. Cytowani autorzy [17] na podstawie przeprowadzonych badań wykazali, że większość kobiet, u których występowały objawy związane z nietrzymaniem moczu były w okresie okołomenopauzalnym lub po menopauzie. Natomiast w badaniach Barnaś i wsp. [18] wykazano, że wraz z wiekiem częstotliwość mikcji $\mathrm{w}$ ciągu doby $\mathrm{u}$ kobiet $\mathrm{z}$ problemem nietrzymania moczu wzrastała, co mogło pogarszać jakość życia. Ponadto Stothers i wsp. [19] na podstawie badań wykazali, że wiek był najistotniejszym czynnikiem, który istotnie warunkował występowanie problemów związanych z codziennym oddawaniem moczu.

Badania własne wykazały, że wykształcenie nie miało wpływu na jakość życia badanych kobiet. Podobne wyniki uzyskali Dutkiewicz i wsp. [7], którzy wykazali brak związku pomiędzy wykształceniem a problemem nietrzymania moczu wśród kobiet objętych badaniem. Z kolei odmienne wyniki uzyskali Barnaś i wsp. [18], ponieważ w badanej grupie kobiet wykształcenie istotnie warunkowało ich jakość życia. Cytowani autorzy [18] wykazali, iż kobiety posiadające wyższe wykształcenie miały lepszą jakość życia, co manifestowało się przyjmowaniem aktywnej postawy wobec problemu nietrzymania moczu. Oznacza to, że kobiety starały się robić wszystko, żeby zwalczyć objawy choroby, odmiennie niż respondentki posiadające wykształcenie średnie lub podstawowe. Przyjmowały one częściej postawę bierną wobec problemu, co automatycznie obniżało ich jakość życia podczas codziennego funkcjonowania. Natomiast Szkup - Jabłońska i wsp. [20] wykazali, że lepszą jakością życia w aspekcie stanu psychicznego charakteryzowały się kobiety posiadające wykształcenie wyższe $\mathrm{w}$ porównaniu do kobiet $\mathrm{z}$ wykształceniem średnim.

Kolejną analizowaną zmienną w kontekście jakości życia była sytuacja finansowa. Na podstawie przeprowadzonych badań własnych stwierdzono, że sytuacja finansowa warunkowała związek objawów pochodzących z układu moczowego na ogólny stan zdrowia, kondycję fizyczną oraz sen. Wykazano również, że kobiety deklarujące przeciętną sytuację finansową wskazywały na gorszą jakość życia w porównaniu do kobiet, które oceniły swoją sytuację finansową na dobrą. Natomiast w badaniach Kamińskiej i wsp. [9] dotyczących społecznego aspektu nietrzymania moczu wśród kobiet wykazano, iż znaczny odsetek badanych kobiet zadeklarował, że choroba wikłająca ich zdrowie istotnie wpływa na pogorszenie ich sytuacji materialnej. Wiąże się to głównie z wydatkami takimi jak leki, produkty chłonne czy wizyty u specjalistów. Sytuacja ta istotnie warunkowała jakość życia, która jest niższa wśród kobiet ze złą sytuacja materialną, aniżeli u respondentek, które swoją sytuację finansową oceniają jako dobrą lub bardzo dobrą.

Reasumując uzyskane wyniki badań własnych należy stwierdzić, że szczególną opieką psychoprofilaktyczną 
należy objąć kobiety powyżej 65. roku życia, będące wdowami lub rozwiedzionymi z przeciętną sytuacją finansową. Powyższe działania mogłyby zapewnić poprawę ich jakości życia.

\section{WNIOSKI}

1. Jakość życia kobiet z nietrzymaniem moczu jest warunkowana przez ich wiek, stan cywilny oraz sytuację finansową.

2. Kobiety powyżej 65. roku życia, będące wdowami lub rozwiedzionymi z przeciętną sytuacją finansową charakteryzują się niższymi wynikami w zakresie jakości życia, niż kobiety z młodszych grup wiekowych, będące mężatkami oraz $\mathrm{z}$ dobrą sytuacją finansową.

\section{REFERENCES/PIŚMIENNICTWO}

1. Radziszewski P, Baranowski W, Nowak-Markwitz E. i wsp. Wytyczne zespołu ekspertów odnośnie postępowania diagnostyczno-terapeutycznego u kobiet z nietrzymaniem moczu i pęcherzem nadreaktywnym. Ginekol. Pol. 2010; 81: 789_ 793.

2. Dębiński P, Niezgoda T. Klasyfikacja nietrzymania moczu i sposoby leczenia. Prz. Urol. 2014; 5: 42-46.

3. Adamczuk J, Kraczkowski JJ, Robak JM, Żurawska vel Dziurawiec K. Czy nietrzymanie moczu to choroba cywilizacyjna? Probl. Hig. Epidemiol. 2011; 92 (3): 382-386.

4. Ogórek-Tęcza B, Pulit A. Nietrzymanie moczu u kobiet a zaburzenia depresyjne. Piel. XXI w. 2012; 1(38): 25-29.

5. Radziszewski P, Bender S, Borowski J, i wsp. Postrzeganie problemu nietrzymania moczu przez kobiety w Polsce. Prz. Menopauz. 2011; 10(5): 405-411.

6. Stadnicka G, Janik M, Łepecka-Klusek C, Pilewska-Kozak A. Psychospołeczne następstwa nietrzymania moczu. Med. Og. Nauki Zdr. 2014; 20(2): 136-140.

7. Dutkiewicz S, Kapusta K. Nietrzymanie moczu a czynniki ryzyka i jakość życia kobiet w Zakładzie Opiekuńczo-Leczniczym w Kielcach. Prz. Menopauz. 2011; 10(6): 493499.

8. Derewiecki T, Mroczek M, Majcher P, Chruściel P. Znaczenie nietrzymania moczu wśród kobiet po 40 roku życia. Hygeia. Public. Health. 2015; 50(1): 219-225.

9. Kamińska A, Kurzeja A, Ogórek-Tęcza B. Jakość życia kobiet z nietrzymaniem moczu. Piel. XXI w. 2012; 4(41): 23-27.

10. Gugała B, Głaz J, Drelich A. Zapotrzebowanie na edukację w zakresie profilaktyki nietrzymania moczu u kobiet. Prz. Med. Uniw. Rzesz. Inst. Leków 2011; 9(3): 340-347.

11. Bender S, Borowski J, Borkowski T, i wsp. Nietrzymanie moczu. Med. Dypl. 2011; 20(6): 74-81.

12. Kelleher CJ, Cardozo LD, Khullar V, Salvatore S. A new questionnaire to assess the quality of life urinary incontinent women. Int. J. Gynecol. Obstet. 1997; 104 (12): 1374-1379.

13. Osowska I, Kurowska K. Nietrzymanie moczu - wstydliwa dolegliwość. Mag. Pieleg. Położ. 2011; 6:12, 14.

14. Özdemir K, Şahin S, Özerdoğan N, Ünsal A. Evaluation of urinary incontinence and quality of life in married women aged between 20 and 49 years (Sakarya, Turkey). Turk. J. Med. Sci. 2018; 48(1): 100-109.

15. Horng SS, Huang N, Wu SI, et al. The epidemiology of urinary incontinence and it's influence on quality of life in Taiwanese middle-aged women. Neurourol. Urodyn. 2013; 32(4): 371-376

16. Basak T, Kok G, Guvenc G. Prevalence, risk factors, and quality of life in Turkish women with urinary incontinence: a synthesis of the literature. Int. Nurs. Rev. 2013; 60(4): 448-460

17. Wójtowicz UA, Płaszewska-Żywko L, Kołacz E. Inkontynencja - cichy problem. Analiza czynników ryzyka. Piel. Chir. Angiol. 2013; 3: 92-97.

18. Barnaś E, Barańska E, Gawlik B, Zych B. Czynniki najbardziej wpływające na jakość życia kobiet z nietrzymaniem moczu. Hygeia. Public. Health. 2015; 50(4): 643-648.

19. Stothers L, Friedman B. Risk factors for the development of stress urinary incontinence in women. Curr. Urol. Rep. 2011; 12(5): 363-369

20. Szkup-JabłońskaM, TutajE,JurczakA,iwsp. Wpływ warunkówsocjodemograficznych na jakość życia kobiet w okresie pomenopauzalnym. Perinatol. Neonatol. Ginekol. 2012, 5(1): 34-38.
Manuscript received/Praca zgłoszona do czasopisma: 28.09.2019

Manuscript accepted/Praca zaakceptowana do druku: 16.12.2019

Translation/Tłumaczenie: Katarzyna Szczekala-Studium Praktycznej Nauki Języków Obcych UM w Lublinie 